\title{
REALIZATION OF SOLAR CELLS BASED ON SILICON/OXIDE JUNCTIONS
}

\author{
G. CAMPET, Z.W. SUN, and P. KEOU \\ Laboratoire de Chimie du Solide du CNRS Université BORDEAUX I, 351 cours de la Libération, \\ 33405 TALENCE cedex, France.
}

Transparent and conductive films of $\mathrm{SrTiO}_{3}$, ITO, and $\mathrm{Tl}_{2} \mathrm{O}_{3}$ have been deposited by R.F. cathodic sputtering and by anodic oxidation onto $\mathrm{Si}$ substrates in order to realize SIS cells. A photoconversion efficiency of $8.8 \%$ has been obtained for $\mathrm{Si} / \mathrm{SiO}_{\mathrm{x}} / \mathrm{Tl}_{2} \mathrm{O}_{3}$ cells. On the other hand for $\mathrm{Si} / \mathrm{SiO}_{\mathrm{x}} / \mathrm{SrTiO}_{3}$ (ITO) the photoconversion efficiency is lower than $1 \%$ because of the too large thickness of the $\mathrm{SiO}_{\mathrm{x}}$ interfacial layer.

Transparent and conductive films of $\mathrm{SrTiO}_{3}$, Indium Tin Oxide (ITO), and $\mathrm{Tl}_{2} \mathrm{O}_{3}$ have been deposited by R.F. cathodic sputtering and by anodic oxidation (tables I and II).

$\mathrm{SrTiO}_{3}$ deposited at room temperature is amorphous and is relatively transparent to visible light $\left(\mathrm{E}_{\mathrm{g}}=3.0 \mathrm{eV}, \alpha=10^{4} \cdot \mathrm{cm}^{-1}\right)$. The Fermi level in this film is pinned at about $0.6 \mathrm{eV}$ under the conduction band edge $\left(\mathrm{E}_{\mathrm{F}}=4.0 \mathrm{eV}\right)$ by the energy states $\mathrm{Ti}^{3+}: 3 \mathrm{~d}^{1}\left(\mathrm{t}_{2 \mathrm{~g}}\right)$ originating from Ti-O dangling bonds ${ }^{1}$. These energy levels are also responsible for the electronic transport in this film $\left(\mu \mathrm{e}\left(25^{\circ} \mathrm{C}\right)=10^{-1} \cdot \mathrm{cm}^{2} /\right.$ $\left.\mathrm{V} \cdot \mathrm{s}, \mathrm{E}_{\mathrm{a}}=0.07 \mathrm{eV}\right)$.

$\mathrm{SrTiO}_{3}$ deposited at $250^{\circ} \mathrm{C}$ under a controlled reductive atmosphere $(60 \% \mathrm{Ar}$ $+40 \% \mathrm{H}_{2}$ ) is partially crystallized (noted as $\mathrm{SrTiO}_{3}$ (p.c.)) and its composition is, in fact, $\mathrm{SrTiO}_{2.8}$. The band gap of the film is reduced to $2.5 \mathrm{eV}$ by the interaction between the $\mathrm{Ti}^{3+}: 3 \mathrm{~d}^{1}\left(\mathrm{t}_{2 \mathrm{~g}}\right)$ non-bonding states. The Fermi level is just near the bottom of the conduction band. The electronic transport is assured by the free electrons in the conduction band $\left(\mu_{e}\left(25^{\circ} \mathrm{C}\right)=60 \mathrm{~cm} / \mathrm{V} \cdot \mathrm{s}, \mathrm{E}_{\mathrm{a}}=0.03 \mathrm{eV}\right)^{2}$.

The energy band diagrams of the films are reported on the Fig. 1.

ITO is amorphous when deposited at room temperature and becomes crystallized when deposited at $250^{\circ} \mathrm{C}$. $\mathrm{Tl}_{2} \mathrm{O}_{3}$ crystallizes in the same structure as ITO.

Both ITO and $\mathrm{Tl}_{2} \mathrm{O}_{3}$ are degenerated $\mathrm{n}^{+}$-type semiconductors. $\mathrm{Tl}_{2} \mathrm{O}_{3}$ is transparent to visible light (like ITO) in spite of its small band energy gap value $\left(\mathrm{E}_{\mathrm{g}}=\right.$ $1.4 \mathrm{eV})$. The conduction band edge of $\mathrm{Tl}_{2} \mathrm{O}_{3}(\mathrm{E} . \mathrm{A} .=5.0 \mathrm{eV})$ is $0.8 \mathrm{eV}$ lower than that of ITO $($ E.A. $=4.2 \mathrm{eV})$. All these phenomena can be explained on the basis of the band energy diagram common for ITO and $\mathrm{Tl}_{2} \mathrm{O}_{3}{ }^{2}$ (Fig. 2). The proposed energy diagram model is in good agreement with that proposed by Switzer ${ }^{3}$.

Because of their transparency, electrical conductivity, and electron affinity, thin films of $\mathrm{SrTiO}_{3}$ (p.c) and ITO have been deposited onto p-Si (100) face, and that of $\mathrm{Tl}_{2} \mathrm{O}_{3}$, onto $\mathrm{n}-\mathrm{Si}(100)$ face, to realize the SIS (Semiconductor-Insulator-Semiconductor) tunnel solar cells (Fig. 3). 


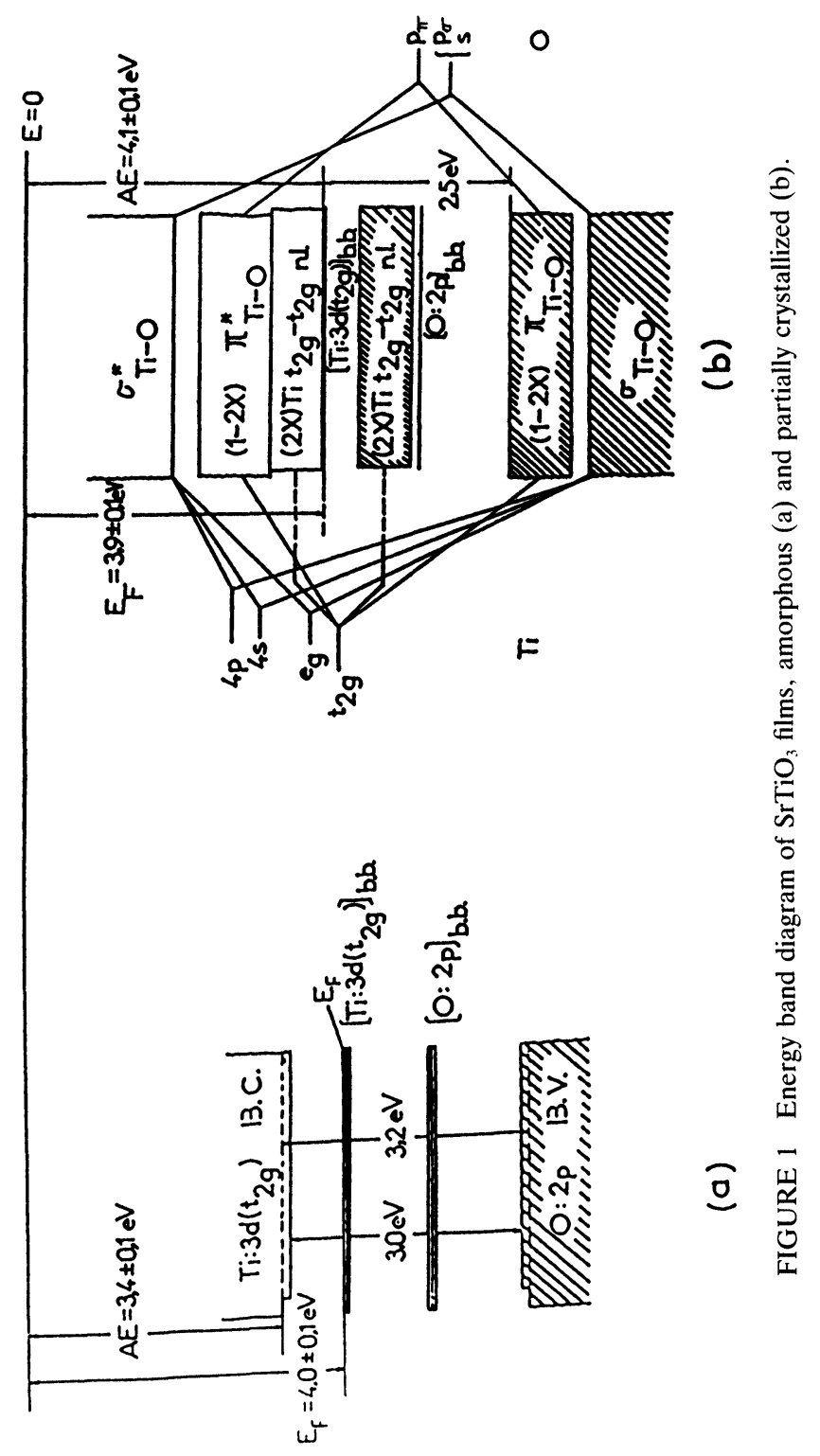


TABLE I

R.F. sputtering deposition condition.

\begin{tabular}{|c|c|c|c|c|}
\hline \multirow[b]{2}{*}{ Film } & \multicolumn{2}{|c|}{ Atmosphere } & \multirow{2}{*}{$\begin{array}{l}\text { Sputtering } \\
\text { power }\end{array}$} & \multirow{2}{*}{$\begin{array}{l}\text { Target-Sub. } \\
\text { distance }\end{array}$} \\
\hline & Compos. & Pressure & & \\
\hline $\mathrm{SrTiO}_{3}$ & $\begin{array}{l}\text { Ar } 60 \% \\
\mathrm{H}_{2} 40 \%\end{array}$ & $\begin{array}{l}1.5 \mathrm{~Pa} \\
0.5 \mathrm{~Pa}\end{array}$ & $150 \mathrm{~W}$ & $5 \mathrm{~cm}$ \\
\hline ITO & $\operatorname{Ar} 100 \%$ & $0.5 \mathrm{~Pa}$ & $55 \mathrm{~W}$ & $7 \mathrm{~cm}$ \\
\hline
\end{tabular}

TABLE II

Anodic oxidation condition for $\mathrm{Tl}_{2} \mathrm{O}_{3}$.

\begin{tabular}{llll}
\hline Substrate & Solution & $\begin{array}{l}\text { Current } \\
\text { intensity }\end{array}$ & $\begin{array}{l}\text { Electrode } \\
\text { potential }\end{array}$ \\
\hline $\mathrm{Ti}$ & $\mathrm{CH}_{3} \mathrm{COOTl} 0.5 \mathrm{M}$ & $5 \mathrm{~mA} / \mathrm{cm}^{2}$ & $* 0.5 \mathrm{~V} / \mathrm{SCE}$ \\
$\mathrm{Si}$ & $+\mathrm{NaOH} 1 \mathrm{M}$ & & $* 0.5$ \\
\hline
\end{tabular}

* Under the illumination of $150 \mathrm{~W}$ Xe-Lamp.

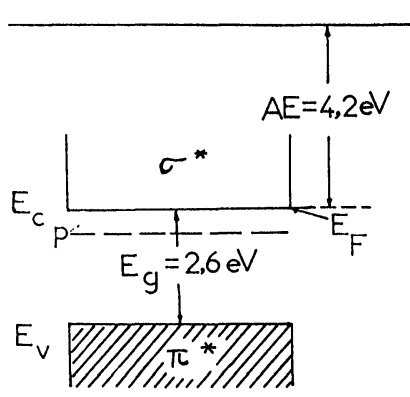

(a)

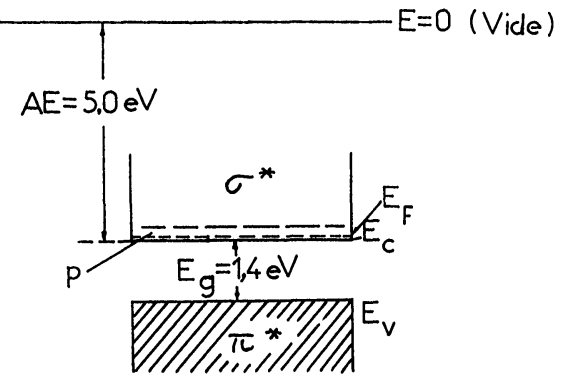

(b)

FIGURE 2 Energy band diagram of ITO (a) and $\mathrm{Tl}_{2} \mathrm{O}_{3}$ (b) films.
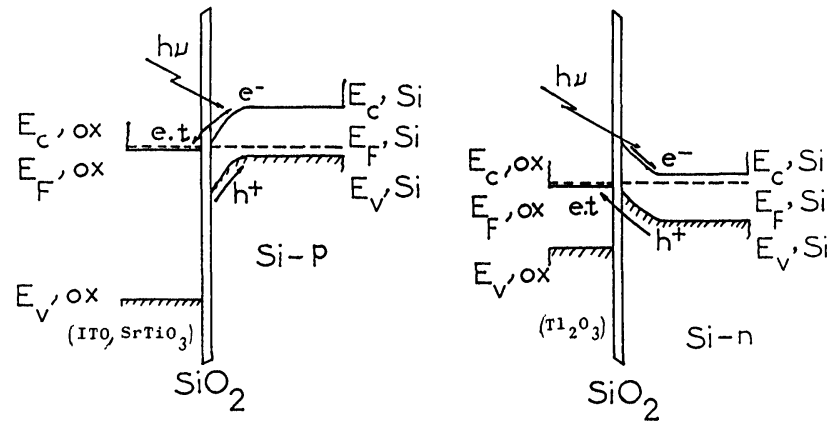

FIGURE 3 Energy band diagram of SIS solar cells. 
TABLE III

The Schottky-barrier heights $\left(\phi_{B}\right)$ of the solar cells.

\begin{tabular}{lll}
\hline Cell & $\begin{array}{l}\phi_{\mathrm{B}} \text { measured by } \\
\text { transient photocurrent }\end{array}$ & $\begin{array}{l}\phi_{B} \text { calculated from } \\
\text { the difference of } \mathrm{E}_{F}\end{array}$ \\
\hline $\mathrm{Si}-\mathrm{p} / \mathrm{SiOx} / \mathrm{ITO}$ & $0.90 \mathrm{eV}$ & $0.93 \mathrm{eV}$ \\
$\mathrm{Si}-\mathrm{p} / \mathrm{SiOx} / \mathrm{SrTiO}_{3}$ & $1.10 \mathrm{eV}$ & $1.23 \mathrm{eV}$ \\
$\mathrm{Si}-\mathrm{n} / \mathrm{SiOx} / \mathrm{Tl}_{2} \mathrm{O}_{3}$ & $1.00 \mathrm{eV}$ & $1.00 \mathrm{eV}$ \\
\hline
\end{tabular}

The ohmic back contact is assured by silver paste on $\mathrm{p}-\mathrm{Si}$, and by an In-Ga eutectic alloy on $\mathrm{n}$-Si. Silver forms the ohmic contact on $\mathrm{p}$-Si because of the alloying effects between $\mathrm{Ag}$ and $\mathrm{SiOx}^{4}$.

Different etching processes of silicon surfaces have been used in order to minimize the influence of the interface states. Thus there is no Fermi level pinning effects observed (Table III).

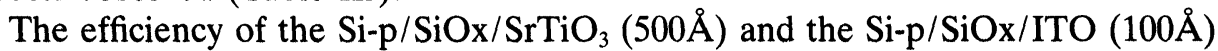
cells are small $(\eta<1 \%)$ because of the existence of a too thick insulating interfacial layer of $\mathrm{SiOx}(\mathrm{d}>20 \AA)$ which is inherent to the experimental conditions (Fig. 4 and 5).

In the case of the $\mathrm{Si}-\mathrm{n} / \mathrm{SiOx} / \mathrm{Tl}_{2} \mathrm{O}_{3}(1000 \AA)$ cells, the thickness of the SiOx layer is appropriate $(10 \AA<\mathrm{d}<20 \AA)$; an efficiency of $8.8 \%$ has thus been obtained (Fig. 6). A semi-theoretical study demonstrates that an efficiency of $12.3 \%$, close to that obtained by A. Switzer ${ }^{3}$, can be achieved by optimizing the etching process of the silicon surface ${ }^{2}$.

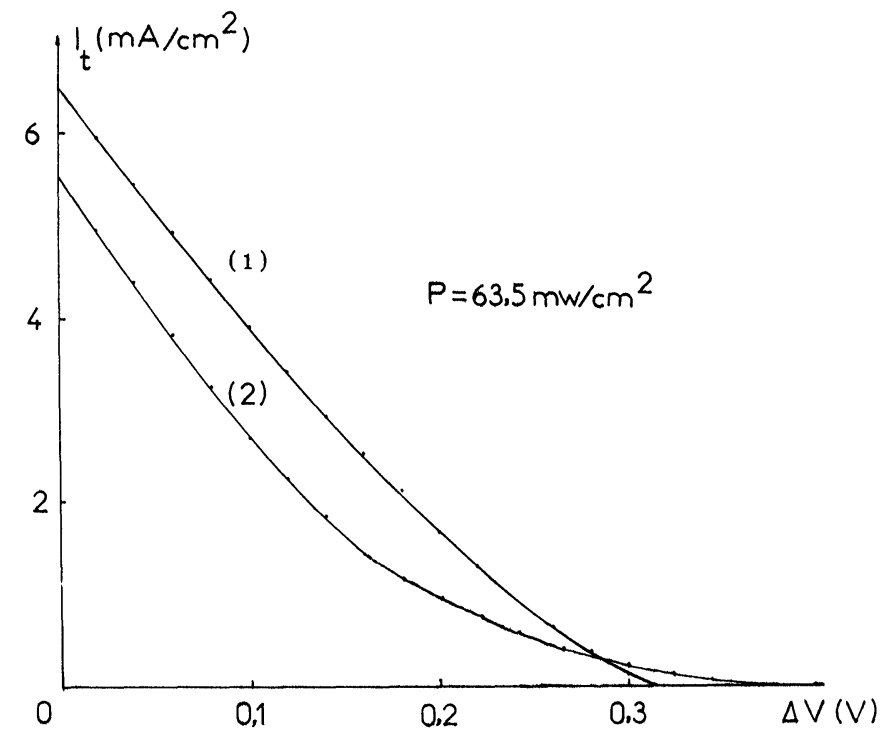

FIGURE 4 I-V characteristics of the solar cells: $\left(\mathrm{d}_{\mathrm{siox}}>20 \AA\right)(1) \mathrm{Si}-\mathrm{p} / \mathrm{SiOx} / \mathrm{ITO}$ (2) Si-p/SiOx/ $\mathrm{SrTiO}_{3}$. 


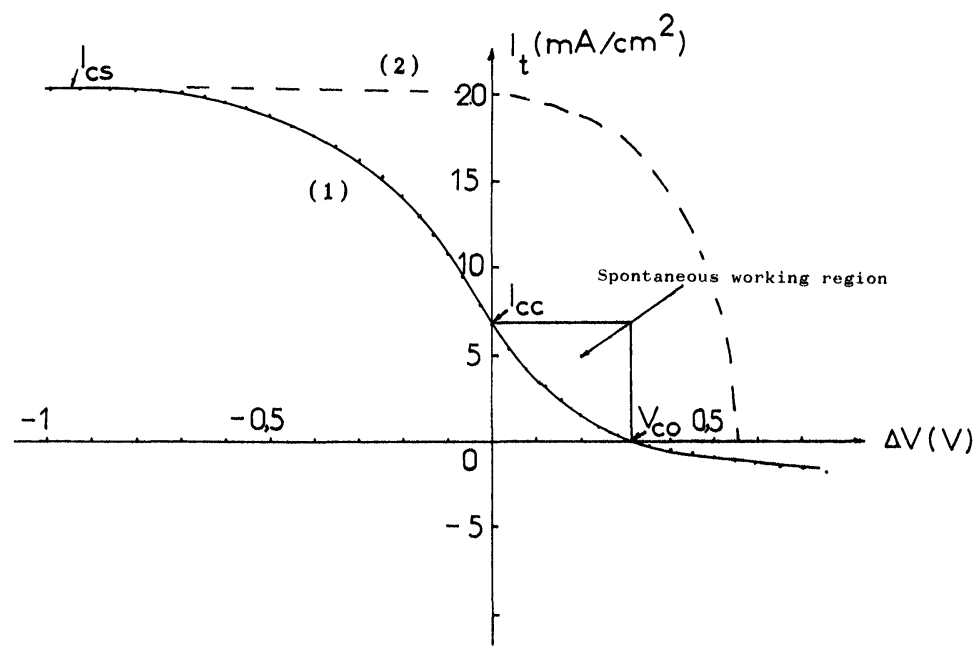

FIGURE 5 I-V characteristics of the Si-p/SiOx/ITO cells: (1) Experimental curve (2) Expected curve if $d_{\mathrm{SO} O \mathrm{~A}}<20 \AA$.

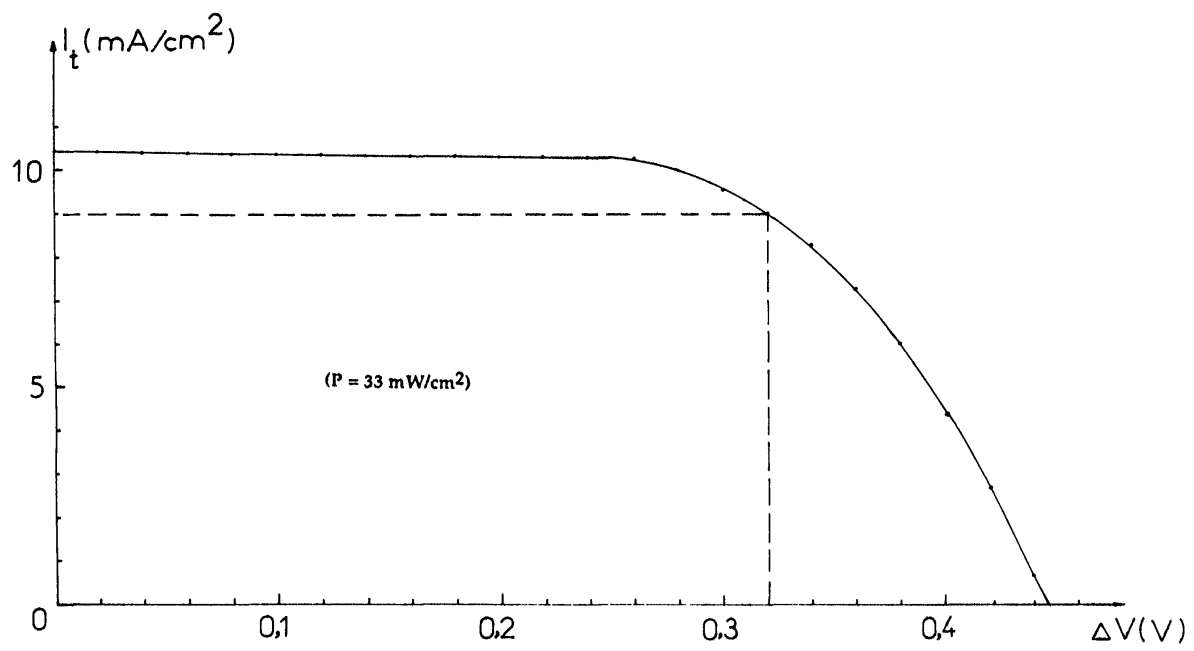

FIGURE 6 I-V characteristics of the $\mathrm{Si}-\mathrm{n} / \mathrm{SiOx} / \mathrm{Tl}_{2} \mathrm{O}_{3}$ cell $\left(10 \AA<\mathrm{d}_{\mathrm{SiOx}}<20 \AA\right)$.

A back-wall MIS solar cell ( $\mathrm{Ag} / \mathrm{SiOx} / \mathrm{Si}-\mathrm{n} / \mathrm{ITO})$ using ITO as transparent ohmic contact material has been demonstrated to be interesting if one can reduce the silicon thickness.

\section{ACKNOWLEDGEMENT}

The authors wish to thank Dr. R. Castellano, editor, Active and Passive Electronic Components, for very helpful discussions. 


\section{REFERENCES}

1. B.T. Chang, G. Campet, J. Claverie and J.B. Goodenough, J. Solid State Chem., 49, 247 (1983).

2. S.W. Sun and G. Campet, Phys. Stat. Sol. (a) (submitted).

3. A. Switzer, J. Electrochem. Soc., 133, 522 (1986).

4. T.E. Sullivan, R.B. Childs, J.M. Ruths, S.J. Fonash in the "Physics of $\mathrm{SiO}_{2}$ and its interfaces" edited by S.T. Pantelides, Pergamon Press, New-York, 454 (1978). 

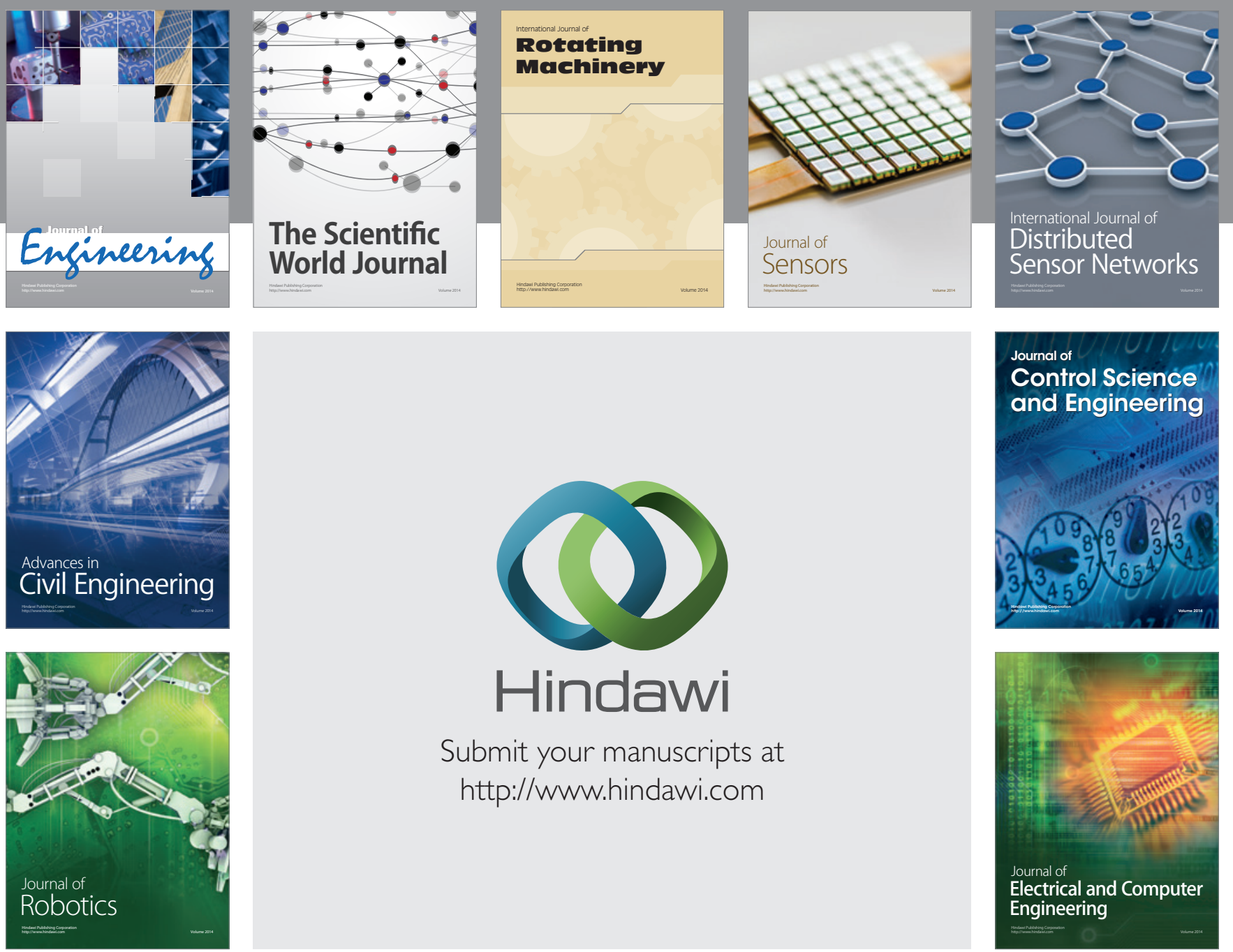

Submit your manuscripts at

http://www.hindawi.com
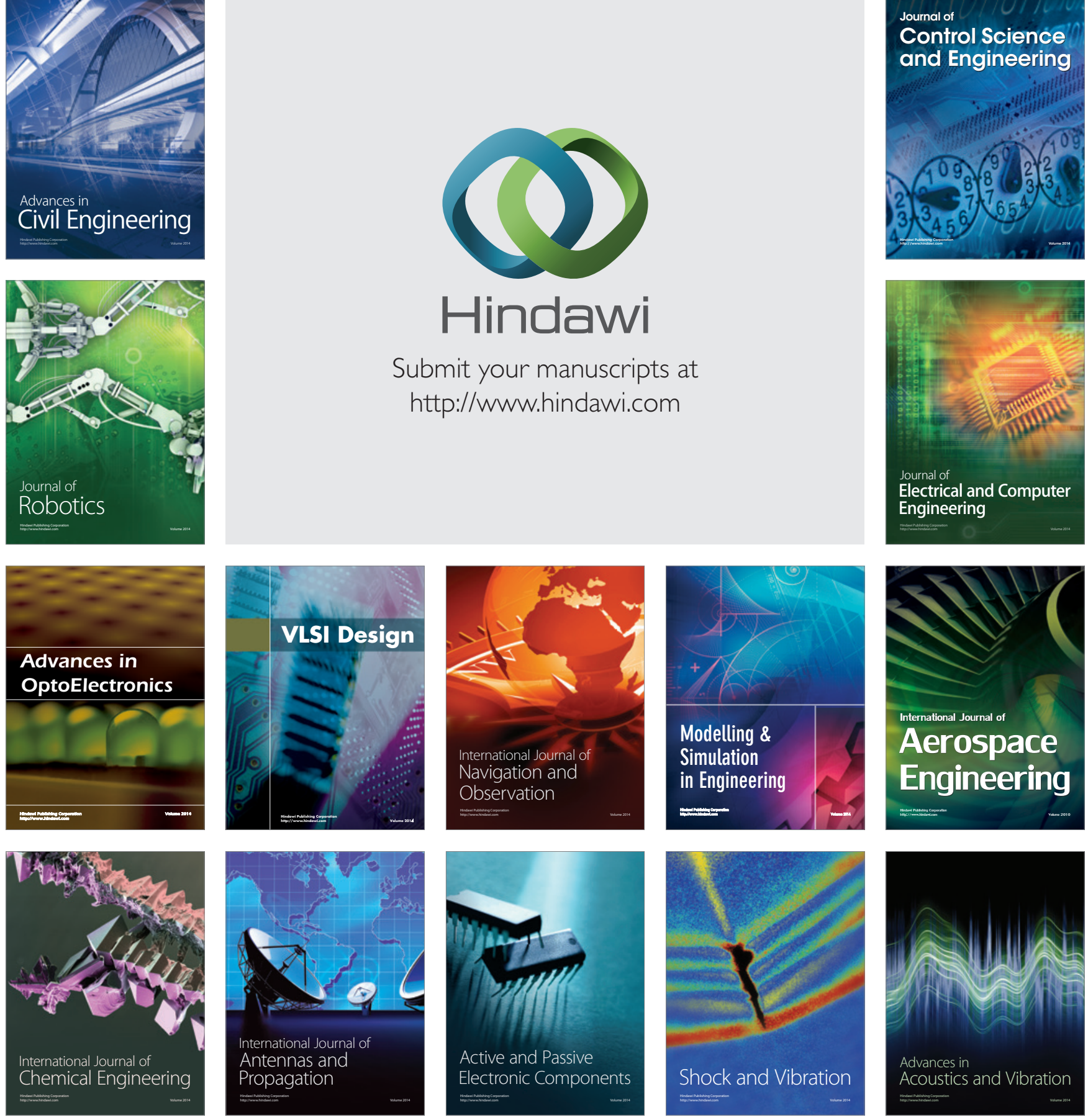